\title{
TECHNOLOGY AND ACADEMIC PLANS OF LAW SCHOOLS IN PORTUGAL
}

\author{
Sónia Rolland Sobral ${ }^{1}$ \\ ${ }^{1}$ Universidade Portucalense (Portugal)
}

\begin{abstract}
Students enrolled in Portuguese higher education in the Law courses of the 2016-2017 and 2017-2018 school year had 15 different courses of study: five in public universities (two of them with post-work placements), two in non-state public education and eight in private universities. More than 1400 public education posts were filled with high average of the last student placed.
\end{abstract}

Although these students have good grades of admission, they lack some skills, particularly in terms of technologies and of their good use, as university students and later as law graduates.

Students coming to university bring little technological knowledge from secondary education since curricula are very poor in this area. In Portugal there is a curriculum in secondary education but not all students were contemplated and often what is taught in these high school subjects is related to internet, blogs or websites (usually taught in a very light way). Usually nothing about office tools, often seen as a poor relative of technology, when in reality they are very powerful means of working (and not only). Although most of the students were born in a digital age, there are many difficulties in terms of basic computer applications from the perspective of the user. In fact, they live surrounded by technology, they use technology to communicate and have fun, and often use digital office applications, but they do so in a very poor and incorrect way. To meet these needs, some of the universities have included in their curriculum some unit's curricula that aim to provide students with the knowledge and skills to handle the technologies and make a good use of them.

This article is part of a study that portrays the technological knowledge of students when they enter a law course, the technological teaching/learning within a course plan in higher education in a law school and after attending technological units provided within a degree, which is the knowledge that the orders intend that the candidates have, as well as the technological needs of the professionals of the different careers that have in common the degree in law. In this article, a study is made of the course plans of the first cycle school year existing in Portugal in the two academics year 2016-2017 and 2017-2018 and list the curricular units that deal with technological concepts and tools. A comparison is made between these different curricular units and suggestions are made for the transmission of computer knowledge to future law graduates.

Keywords: curriculum; technology.

\section{INTRODUCTION}

The Law course in Portugal always has many candidates and places. Courses require high averages (numerus clausulus) but do not impose prerequisites. It turns out that students upon entering a law course do not have a high level of user-level technology knowledge that they need in their professional future: "The generalized view that 18-25 year olds are experts in technology may not be the most correct "and" It is clear that young people of the generation $Z$ enter the university with a lot of technology, but with very little knowledge of MsOffice. It will be necessary to provide these skills to the students so they can do their academic work and know how to use them in future work life. " [1] [2]. The university will be a way to prepare students who enter secondary education for professional life and technology is a very important tool in the life of a professional in the area of law.

\section{LAW SCHOOLS IN PORTUGAL}

The Law course in Portugal is taught in 15 different universities, two of which distinguish the vacancies for "normal" students and post-employment students (University of Lisbon and University of Minho) according to the Directorate General of Higher Education [3]. Considering the last two academic years and according to the Type of University Higher Education: in 2016 were placed 2441 (Public 1426 and 
Private 1015) and in 2017 entered 2558 students (Public 1413 and Private 1145). There are also students who enter the Portuguese Catholic University that do not provide entrance data.

Table 1. Number of Students Placed in Law Courses in Portugal.

\begin{tabular}{|c|c|c|c|c|}
\hline \multirow[b]{2}{*}{ Public } & \multicolumn{2}{|c|}{ Placed 2016} & \multicolumn{2}{|c|}{ Placed 2017} \\
\hline & $\begin{array}{c}1^{\text {st }} \\
\text { stage }\end{array}$ & $\begin{array}{c}2^{\text {nd }} \\
\text { stage }\end{array}$ & $\begin{array}{c}1^{\text {st }} \\
\text { stage }\end{array}$ & $\begin{array}{c}2^{\text {nd }} \\
\text { stage }\end{array}$ \\
\hline Universidade de Coimbra & 334 & 28 & 334 & 30 \\
\hline Universidade de Lisboa & 460 & 66 & 560 & 74 \\
\hline Universidade de Lisboa (PL) & 100 & 14 & 0 & 0 \\
\hline Universidade do Minho & 110 & 10 & 110 & 4 \\
\hline Universidade do Minho (PL) & 16 & 3 & 15 & 1 \\
\hline Universidade do Porto & 155 & 19 & 155 & 17 \\
\hline \multirow[t]{2}{*}{ Universidade Nova de Lisboa } & 100 & 11 & 100 & 13 \\
\hline & 1275 & 151 & 1274 & 139 \\
\hline Private & \multicolumn{2}{|c|}{2016} & \multicolumn{2}{|c|}{2017} \\
\hline IS Manuel Teixeira Gomes & \multicolumn{2}{|c|}{50} & \multicolumn{2}{|c|}{50} \\
\hline Universidade Autónoma & \multicolumn{2}{|c|}{170} & \multicolumn{2}{|c|}{170} \\
\hline Universidade Europeia & \multicolumn{2}{|c|}{25} & \multicolumn{2}{|c|}{50} \\
\hline Universidade Lusíada & \multicolumn{2}{|c|}{150} & \multicolumn{2}{|c|}{175} \\
\hline Universidade Lusíada Porto & \multicolumn{2}{|c|}{200} & \multicolumn{2}{|c|}{250} \\
\hline Universidade Lusófona & \multicolumn{2}{|c|}{150} & \multicolumn{2}{|c|}{150} \\
\hline Universidade Lusófona do Porto & \multicolumn{2}{|c|}{100} & \multicolumn{2}{|c|}{120} \\
\hline \multirow[t]{2}{*}{ Universidade Portucalense } & \multicolumn{2}{|c|}{170} & \multicolumn{2}{|c|}{180} \\
\hline & \multicolumn{2}{|c|}{1015} & \multicolumn{2}{|c|}{1145} \\
\hline Catholica & \multicolumn{2}{|c|}{2016} & \multicolumn{2}{|c|}{2017} \\
\hline Universidade Católica Pt & \multicolumn{2}{|c|}{ ND } & \multicolumn{2}{|c|}{ ND } \\
\hline \multirow[t]{2}{*}{ Universidade Católica Pt (Porto) } & \multicolumn{2}{|c|}{ ND } & \multicolumn{2}{|c|}{ ND } \\
\hline & 2290 & 151 & 2419 & 139 \\
\hline
\end{tabular}

Portugal has a numerus clasulus system in which each University can choose the classification formula of the access. As an example, to enter the Law course of the University of Porto, "Currently, the access requirements are: to be the owner of the 12th. Year and carry out the entrance tests (Portuguese or History) " [4]. They do not define prerequisites and the minimum access grade is 120 points in 200. The average is calculated taking into account the grades of secondary education and one of the access exams, in this case being $40 \%$.

The average admission rates (we will only consider those of public universities) differ according to the university of choice: between 135.5 at the University of Lisbon (post-employment regime) in the first phase of 2016 and 17.2 at the University of Porto and second phase.

Table 2. Average of the last student placed.

\begin{tabular}{|l|c|c|c|c|}
\cline { 2 - 5 } \multicolumn{1}{c|}{} & \multicolumn{2}{c|}{ Lowest 2016} & \multicolumn{2}{c|}{ Lowest 2017} \\
\hline Public & $\begin{array}{c}1^{\text {st }} \\
\text { stage }\end{array}$ & $\begin{array}{c}2^{\text {nd }} \\
\text { stage }\end{array}$ & $\begin{array}{c}1^{\text {st }} \\
\text { stage }\end{array}$ & $\begin{array}{c}2^{\text {nd }} \\
\text { stage }\end{array}$ \\
\hline Universidade de Lisboa (PL) & 135,5 & 143 & NA & NA \\
\hline Universidade do Minho (PL) & 155 & 158 & 162,6 & 168,6 \\
\hline Universidade de Coimbra & 145,5 & 148,3 & 146,8 & 148,3 \\
\hline Universidade de Lisboa & 144 & 146,3 & 145,5 & 146,5 \\
\hline Universidade do Minho & 159 & 164 & 164,4 & 170 \\
\hline Universidade Nova de Lisboa & 157 & 156,8 & 160,5 & 154,8 \\
\hline Universidade do Porto & 167,8 & 169,2 & 170,6 & 172 \\
\hline
\end{tabular}




\section{TECHNOLOGY, LAW SCHOOLS, PORTUGAL}

By reviewing the course plans (and sending email to coordinator / course director to confirm the information), we find that very few courses provide curriculum units with IT content.

In the academic year 2016-2017, we verified that of the 15 Law courses in Portugal, only four Universities offer some technological curricular unit. Curiously, none of these universities is public. In the academic year 2017-2018 only three Universities offer some technological curricular units.

At the University Lusíada (Porto and Lisbon) there is a curricular unit called METHODOLOGY OF INFORMATION RESEARCH AND TECHNOLOGY, offered both in the academic year started in 2016 and in what began in 2017. It is the first semester of the first year and has 3 ECTS and 2 hours per week [5] [6]. The objective is to "Support the student in the search and application of the methodology and research techniques most appropriate to the completion of studies and works in the degree." And in the program contents there is "The importance of the new technologies of information and communication".

At the Catholic University of Portugal - Faculty of Law (Porto) there is a curricular unit called Information Technologies, classified as instrumental (at the same level of the English language) [7].The program is "A. Technologies and Society. Knowledge and Documentation Management C. Individual Productivity Tools C. Text Processing C2 Worksheets C3 Electronic Presentations D. Technology and Mobility "It is verified that this CU may not be mandatory appearing in the course plan as an "Optional Non-Juridical" offered in the first 4 semesters [8].

At the Portucalense University there was "Information and Knowledge Society" [9] in the 2016-2017 school year and that does not exist in the course plan in the 2017-2018 school year. The curricular unit had 3 ECTS and 3 hours per week divided into seminars and laboratories. The program consisted of "1. Information Technology (IT) in the information and knowledge society1.1. Perspectives on the impacts of IT 1.2. Changing organizational structures and habits 1.3. The importance of information 1.4. IT is performing functions previously performed by human beings 2. IT infrastructures 2.1. Hardware Infrastructure Components 2.2. Software platforms 2.3. Mobile platforms 2.4. Internet and computer networks 3. Social, ethical and legal aspects of IT 4. Emerging and disruptive technologies 5. Work support tools in the context of the course ", with the latter being used tools from MsOffice.

The European University does not have its course plan online; the coordinator do not responded to the email.

It should be noted that up to 2016, the Law course of the Autonomous University had a curricular unit called "Informatics for lawyers" [10] whose program was "Provide an overview of the possibilities offered by IT as a working tool for the Jurist. Acquire some basic skills in the handling of different tools: Text Processors, Sheets of Calculus, Multimedia Presentations, Internet, Search Engines, and Legal Databases. Understand the implications of Information and Communication Technologies in Law. Dangers and potential of electronic documents in general and electronic mail and internet in particular. Identify problems and threats resulting from the use of technologies, including the Internet and related to security, information privacy and computer piracy. Address various aspects related to the processing of Personal Data, Electronic Commerce, Digital Certificates (electronic signature), Electronic Law (contracts), Informatics and Law and their implications in the information society. "

Until 2014, the Portucalense University also had in its course of law a curricular unit called Informatics for jurists whose program was very similar to the Information and Knowledge Society that took place in the years 2015-2016 and 2016-2017.

\section{CONCLUSIONS}

Although we have verified in other previous articles that the students enter the degrees in Law without technological knowledge that are very important for their future career, few Universities that offer in curricula curricular units with computer science and technology. Interestingly there are more and more University that include technical English and German technical in their plans of law course. 
In this article, we find that in 2016-2017 only four courses presented a technological curricular unit in their plans, and in 2017-2018 this number dropped to three.

In an upcoming article we will write about the presence of these curricular units in Universities of reference worldwide, as well as what the knowledge that a professional of the area of Law needs when entering the world of work. Finally, we will make several recommendations that we hope will be taken into consideration by those who draw up course plans in law.

\section{REFERENCES}

[1] S. R. Sobral, "DIGITAL NATIVES: A GENERATION ZAPPING THE LESS FUN TECHNOLOGY," em 8th annual International Conference of Education, Research and Innovation, Sevilla, 2015.

[2] S. R. Sobral, "TECHNOLOGY AND THE YOUTH OF THE GENERATION Z: A CASE STUDY OF COLLEGE STUDENTS AT A LAW SCHOOL," em 8th annual International Conference on Education and New Learning Technologies, Barcelona, 2016.

[3] Direção-Geral do Ensino Superior, “DGES," Lisboa, 2017.

[4] FDUP, "Informação para candidatos," FDUP, Porto, 2017.

[5] Universidade Lusiada do Porto, "ULP," 2017. [Online]. Available: http://www.por.ulusiada.pt/cursos/1 ciclo/programa.php?v=pt\&cp=023\&uc=02305\&pld=3789. [Acedido em 2017].

[6] Universidade Lusíada de Lisboa, "METODOLOGIA DA INVESTIGAÇÃO E TECNOLOGIA DA INFORMAÇÃO,” 2017. [Online]. Available: http://sv.lis.ulusiada.pt/DocsPDF/p_02305_2017.pdf. [Acedido em 2017].

[7] U. C. d. Porto, "Tecnologias Informacao," 2017. [Online]. Available: http://www.direito.porto.ucp.pt/Disciplinas-Licenciatura-Direito\#TecnologiasInformacao. [Acedido em 2017].

[8] U. C. d. Porto, "Faculdade de Direito | Guia do Candidato | Licenciatura," 2017. [Online]. Available: https://www.porto.ucp.pt/sites/default/files/files/direito/Guias/guia_licenciaturas_direito.pdf. [Acedido em 2017].

[9] Universidade Portucalense, "Ficha da Unidade Curricular 2016/2017, Sociedade da Informação e do Conhecimento," $2016 . \quad$ [Online]. Available: https://siupt.upt.pt/aulas/ficha_uc_impressao.php?df_id=2868. [Acedido em 2016].

[1 U. A. d. L. L. d. Camões, "Plano Direito até 2016," 2016. [Online]. Available:

0] https://ual.pt/pt/unidades.asp?id=2936\&section=/universidade_autonoma/Departamentos/Direito/ Licenciatura/Plano_Curricular\&mid=433. [Acedido em 2017]. 